\title{
RELATION BETWEEN FRAGMENTED QRS COMPLEX AND ARTERIAL COMPLIANCE IN ASYMPTOMATIC HYPERTENSIVE PATIENTS
}

\author{
Asemptomatik Hipertansif Hastalarda Parçalanmış QRS Kompleksi ile Arteryel Komplians \\ Arasındaki İlişki
}

\section{Sinan ŞAHIN ${ }^{1}$ (D), Ahmet ÖZDERYA ${ }^{1}$ (D), Selim KUL ${ }^{1}$ (D), Muhammet Raşit SAYIN ${ }^{1}$ (D), Ömer Faruk ÇIRAKOĞLU1 ${ }^{1}$, Levent KORKMAZ1 ${ }^{1}$, Ali Rıza AKYÜZ1 ${ }^{1}$}

${ }^{I}$ Trabzon Ahi Evren Thoracic and Cardiovascular Surgery Health Practice and Research Hospital, Cardiology Department, TRABZON, TÜRKIYE

\section{ABSTRACT}

Objective: Decreased arterial compliance is among the earliest detectable findings of adverse structural and functional changes in the vessel wall and it results in stiffened arteries. The goal of this study was to explore the relationship between fragmented QRS in electocardiogram and arterial compliance.

Material and Methods: Eighty asymptomatic hypertensive patients with fragmented QRS (40 male, mean age: $58 \pm 8 /$ years) and 80 age-gender matched control subjects

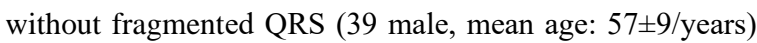
were enrolled. Arterial compliance was calculated as stroke volume to pulse pressure ratio and adjusted to body surface area to calculate the stroke volume to pulse pressure index. The fragmented QRS complexes were investigated in the 12-lead electrocardiogram.

Results: Patients wih fragmented QRS had significantly lower arterial compliance $\left(0.71 \pm 0.29 \mathrm{~mL} / \mathrm{m}^{2} / \mathrm{mmHg}\right.$ versus $\left.0.93 \pm 0.32 \mathrm{~mL} / \mathrm{m}^{2} / \mathrm{mmHg} ; \mathrm{p}<0.001\right)$. A univariate analysis showed a significant correlation between decreased arterial compliance and fragmented QRS, age, and calcium channel blocker use. Multivariable analysis demonstrated age (95\%CI): 0697-0.830; $\mathrm{p}<0.001)$ and fragmented QRS (95\%CI): $0.06-0.536 ; \quad \mathrm{p}=0.002) \quad$ as independent determinants of reduced arterial compliance.

Conclusion: The avaliability of fragmented QRS in electrocardiogram may have significant predictive information of arterial compliance in hypertensive subjects.

Keywords: Arterial cmpliance, fragmented QRS, hypertension

\section{ÖZ}

Amaç: Azalmış arteryel komplians, damar duvarındaki olumsuz yapısal ve fonksiyonel değişikliklerin en erken tespit edilebilen bulgusudur ve ilerleyen zamanda damar sertliği ile sonuçlanır. Bu çalışmanın amacı, elektrokardiyogramdaki parçalanmış QRS ile arteryel uyum arasındaki ilişkiyi araştırmaktır.

Gereç ve Yöntemler: Parçalanmış QRS'li 80 asemptomatik hipertansif hasta (40 erkek, ortalama yaş: $58 \pm 8 / \mathrm{y} 1$ ) ve parçalanmış QRS'siz 80 yaş-cinsiyet eşleştirilmiş kontrol

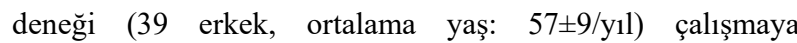
kaydedildi. Arteryel komplians, vuruş hacmi/nabız basıncı oranı olarak hesaplandı ve vuruş hacmi/nabız basıncı indeksini hesaplamak için vücut yüzey alanına göre ayarlandı. Parçalanmış QRS kompleksleri 12 kanallı elektrokardiyogramda incelendi.

Bulgular: Parçalanmış QRS'li hastalar anlamlı olarak daha düşük arteryel kompliansa sahipti $\quad(0.71 \pm 0.29$ $\mathrm{mL} / \mathrm{m}^{2} / \mathrm{mmHg}$ 'ye karş1 $0.93 \pm 032 \mathrm{~mL} / \mathrm{m}^{2} / \mathrm{mmHg}$; p<0.001). Tek değişkenli analiz, azalmış arteryel komplians ile parçalanmış QRS, yaş ve kalsiyum kanal bloker kullanımı arasında anlamlı bir korelasyon gösterdi. Çoklu ikili lojistik regresyon analizi, azalmış arteryel kompliansın bağımsız belirleyicileri olarak yaşı (\%95CI): 0697-0.830; p <0.001) ve parçalanmış QRS'i (\%95CI): 0.06-0.536; p=0.002) göstermiştir.

Sonuç: Parçalanmış QRS'in elektrokardiyogramda bulunması, hipertansif hastalarda arteryel komplians ile ilgili önemli prediktif bilgi sağlayabilir.

Anahtar Kelimeler: Arteryel komplians, parçalanmış QRS, hipertansiyon 


\section{INTRODUCTION}

Hypertension (HT) is a crucial health care problem worldwide. As well as HT associated with morbidity and mortality, elevated blood pressure (BP) also takes a leading role in cardiovascular diseases (CVD) (1). Hypertension changes the properties, structure, and function of arterial blood vessels, a process that evolves long before the advent of overt CVD. A sustained increase in BP often leads to increased stiffness and decreased compliance of large arteries (2). This situation leads to myocyte hypertrophy and fibrosis while increasing left ventricular afterload and wall stress, that show myocardial remodeling in hypertensive patients (3).

Electrocardiogram (ECG) is a simple, painless, noninvasive test that evaluates the heart function by measuring the electrical activity of the myocardium. Myocardial fibrosis may change QRS morphology on surface ECG with no changes in lengthening and its duration, thereby resulting in fragmented QRS (fQRS) complex (additional notch or $\mathrm{R}^{\prime}$ in either the $\mathrm{R}$ or $\mathrm{S}$ wave within a narrow QRS complex) (4). QRS complexes primarily present ventricular depolarization and may give important information about morphological assessment of QRS complex.

In this study, the relationship beween fQRS and reduced arterial compliance (AC) was studied in hypertensive patients.

\section{MATERIALS AND METHODS}

This study was planned as a case-controlled observational study. We observed 80 patients whose fQRS on surface ECG at our clinic. These patients were diagnosed with HT according to the ESC/ESH criteria (5). Age-gender matched 80 hypertensive patients without fQRS were enrolled as the control group. All of procedures that performed in this study were in accordance with the ethical standards of the responsible committee on human experimentation (institutional and national) and with the Declaration of Helsinki (1975), as revised in 2000. This study was approved by Kanuni Education and Research Hospital Clinical Research Ethics Committee, (Date: 17.02.2016; issue number: 2015/53).

Exclusion criteria for selecting the patients were as follows: history of coronary artery disease, transient ischemia, stroke, intermittent claudication; arrhytmia including atrial fibrilation, bundle branch or fascicular block, individuals who have systemic and metabolic diseases that may negatively affect the cardiac structure and functions were excluded from the study. Besides, none of the subjects were using antiarrhythmic drugs, digitalis, or any other QT prolonging medications.

Each subject was questioned about medical history, smoking status, and drug use. If systolic blood pressure was $>140 \mathrm{mmHg}$ and diastolic pressure was >90 $\mathrm{mmHg}$ or there was a history of using any antihypertensive drug, subjects were considered as hypertensive subjects. Subjects with fasting glucose $\geq 126 \mathrm{mg} / \mathrm{dl}$ or using any anti-diabetic treatment were considered as diabetic. Subjects were considered as hyperlipidemic if total cholesterol was $>200 \mathrm{mg} / \mathrm{dL}$ or if they were taking lipid-lowering medications.

\section{Assessment of Arterial Compliance}

Echocardiographic evaluation was accomplished in a left lateral decubitus position. Echocardiographic imaging was performed with a Vivid S5 (General Electric, Horten, Norway) device with a $2.5 \mathrm{MHz}$ probe and carried out by one experienced physician, who was blinded to the subjects' clinical and demographic data. Measurements were made according to the American Society of Echocardiography guidelines and were reported as the average of three cardiac cycles. LV stroke volume (SV) was obtained by the LV outflow tract that is common method for measurement and divided to body surface area to acquire the SV index. Systemic BP was calculated 
using a cuff sphygmomanometer while evaluating Doppler SV in the left ventricular outflow tract. Brachial pulse pressure (PP) was defined as the difference between systolic and diastolic BP, and the ratio of $\mathrm{SV}$ index to $\mathrm{PP}(\mathrm{SV} / \mathrm{PPi})$ was considered as an indirect measure of AC. Normal and decreased AC were defined as $\mathrm{SV} / \mathrm{PPi} \geq 0.6 \mathrm{~mL} / \mathrm{m}^{2} / \mathrm{mmHg}$ and SV/PPi $<0.6 \mathrm{~mL} / \mathrm{m}^{2} / \mathrm{mmHg}$, respectively (6).

\section{Electrocardiographic Assessment}

A 12-lead standard surface electrocardiogram (ECG) (filtering range $0.15-100 \mathrm{~Hz}, \mathrm{AC}$ filtering $50 \mathrm{~Hz}, 25$ $\mathrm{mm} / \mathrm{s}, 10 \mathrm{~mm} / \mathrm{V}$ ) was collected from the all subjects. fQRS was defined as an additional $R$ wave (R'), with or without a $\mathrm{Q}$ wave, or a notch in the of the $\mathrm{R}$ or $\mathrm{S}$ wave, as well as the presence of more than one R' (fragmentation) in 2 adjacent leads without typical bundle branch block (QRS>120ms) and incomplete right bundle branch block. The ECGs were analyzed by a single operator who was blinded to the patients' clinical and laboratory characteristics.

\section{Statistical Analysis}

SPSS 16.0 for Windows (SPSS Inc., Chicago, IL, USA) was used for statistical analyses. An analysis of normality of the continuous variables was evaluated with the Kolmogorov-Smirnov test. Normally distributed continous variables were reported as mean+standard deviation, and categorical variables were defined as number and percentage. Normally distributed variables were analyzed with Student's T test, non-normally distributed variables were compared by Mann-Whitney U test. Categorical variables were compared using the Chi-square test. Logistic regression analysis was used to show the association between fQRS and arterial compliance. Variables with a $p$ value of $\leq 0.05$ were included in logistic regression analysis. A $p<0.05$ was considered statistically significant.

\section{RESULTS}

Table 1 provides an overview of the intercorrelations among the groups in term of clinical characteristics, AC compliance and medications. There was no difference in clinical characteristics and medications in both groups. Patients with fQRS had lower SV/PPi values compared to those who did not have fQRS $(0.71 \pm 0.29$ versus $0.93 \pm 0.32 ; \mathrm{p}<0.001)$ (Figure 1$)$.

The patients were divided into two groups according to the SV/PPi values. The breakdown is as follows: 48 had decreased arterial compliance (SV/PPi<0.6), 112 patients had normal arterial compliance ( $\mathrm{SV} / \mathrm{PPi} \geq 0.6)$ (Table 2). Frequency of fQRS in the groups were as follows: $31(64 \%)$ patients in decreased AC, 50 (44\%) patients in normal AC groups $(\mathrm{p}=0.021)$ (Figure 2). Univariate analysis showed a significant association between decreased AC with fQRS, age and calcium channel bloker use. Multivariable analysis demonstrated age $[95 \%$ Confidence of interval (CI):1.024(0.697-0.830); $\quad \mathrm{p}<0.001]$ and fQRS [95\%CI):2.26(0.06-0.536); $\mathrm{p}=0.002]$ as independent determinant of decreased AC (Table 3). 


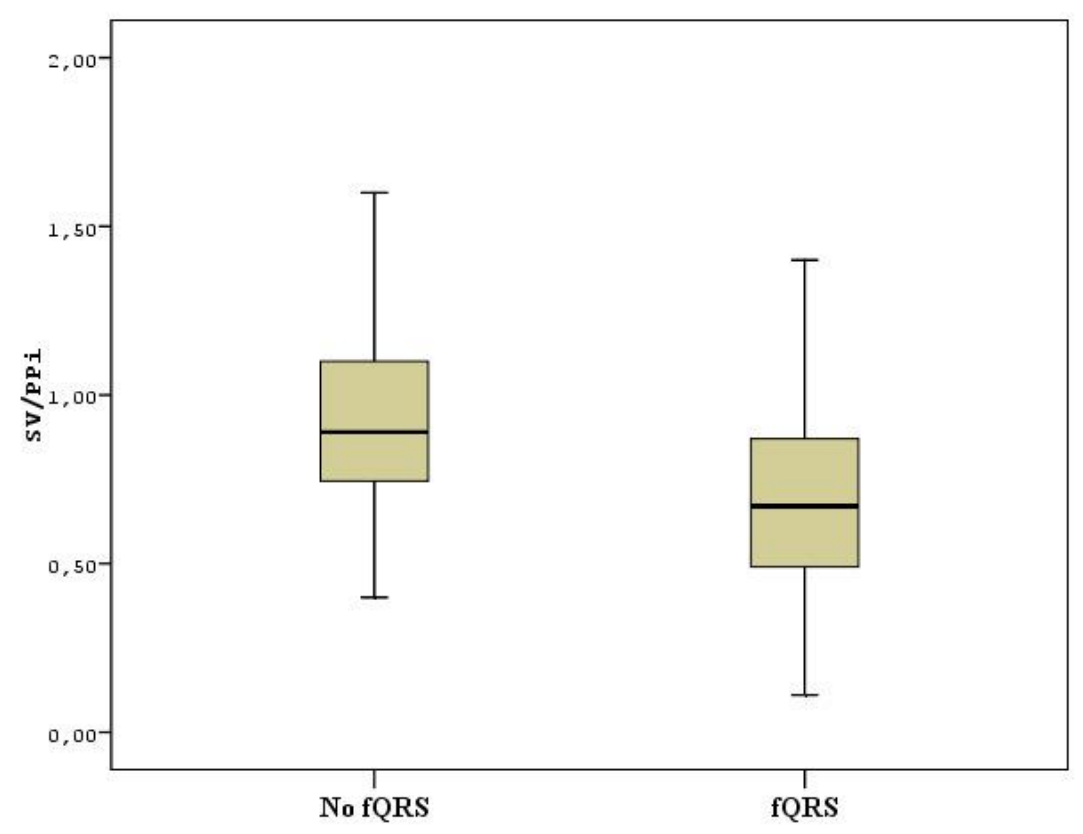

Figure 1: Number of subjects with and with out fQRS according to the cut off SV/PPi values. (SV/PPi, ratio of stroke volume to pulse pressure; fQRS, fragmented QRS)

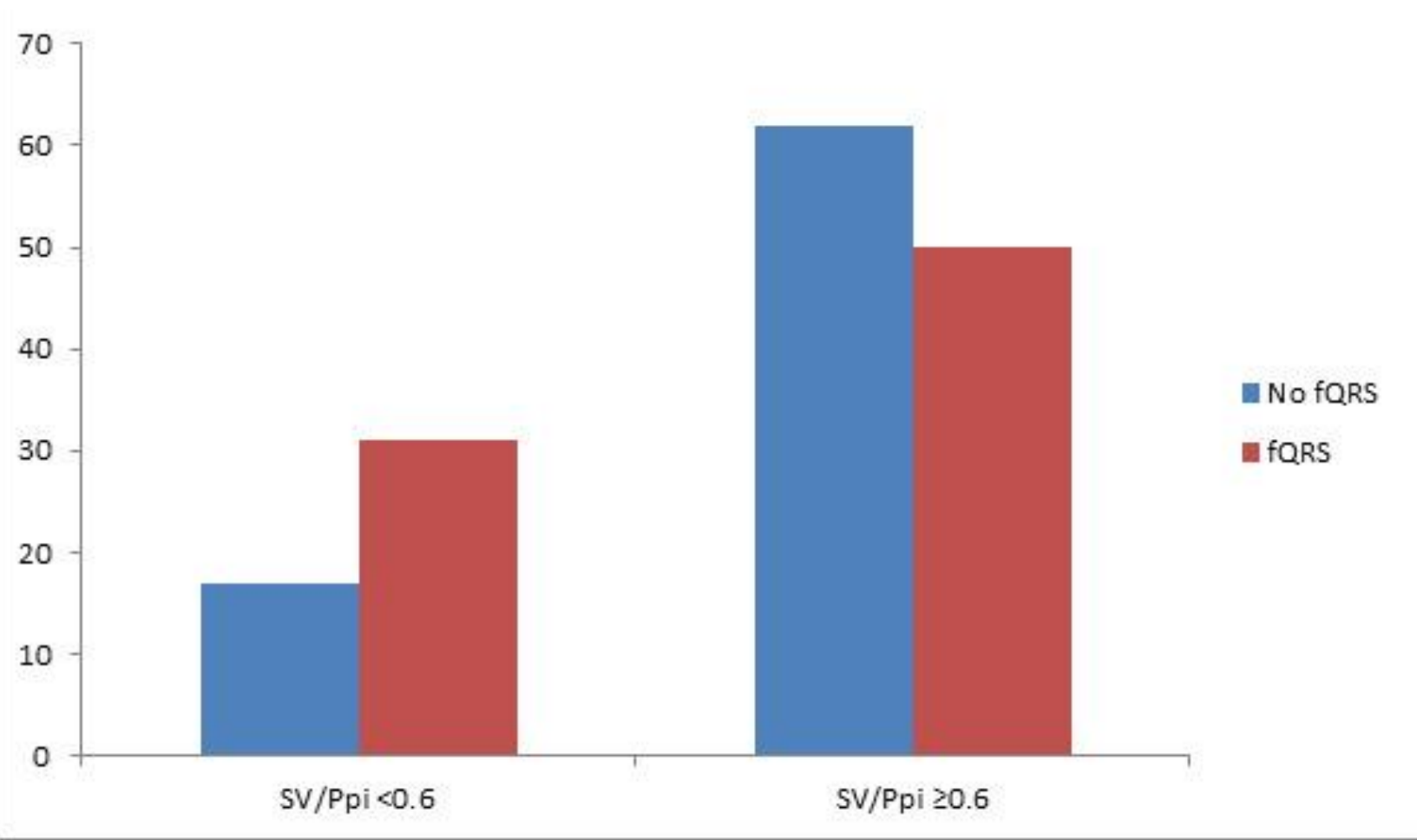

Figure 2: Number of subjects with and without fQRS according to the cut off SV/PPi values. (SV/PPi, ratio of stroke volume to pulse pressure; fQRS, fragmented QRS) 
Table 1: Clinical and laboratory characteristics of subjects

\begin{tabular}{|c|c|c|c|}
\hline Variables & fQRS (+), $n=80$ & fQRS (-), n=80 & $\mathbf{p}$ \\
\hline Age, years (mean \pm SD) & $58 \pm 8$ & $57 \pm 9$ & 0.73 \\
\hline Male gender, n (\%) & $40(50)$ & $39(49)$ & 0.54 \\
\hline Smoking, n (\%) & $17(21)$ & $18(22)$ & 0.78 \\
\hline Diabetes, n (\%) & $11(14)$ & $16(20)$ & 0.29 \\
\hline Dyslipidemia, $\mathrm{n}(\%)$ & $68(85)$ & $64(80)$ & 0.41 \\
\hline $\mathrm{SV} / \mathrm{PPi}, \mathrm{mL} / \mathrm{m}^{2} / \mathrm{mmHg}$ & $0.71 \pm 0.29$ & $0.93 \pm 0.32$ & $<0.001$ \\
\hline $\mathrm{LDL}_{-\mathrm{C}}(\mathrm{mg} / \mathrm{dl})$ & $135 \pm 36$ & $138 \pm 37$ & 0.76 \\
\hline HDL (mg/dl) & $48 \pm 13$ & $47 \pm 13$ & 0.31 \\
\hline Triglyceride (mg/dl) & $150 \pm 58$ & $153 \pm 49$ & 0.53 \\
\hline Cholesterol (mg/dl) & $210 \pm 42$ & $217 \pm 50$ & 0.36 \\
\hline Systolic pressure $(\mathrm{mmHg})$ & $156 \pm 15$ & $153 \pm 14$ & 0.4 \\
\hline Diastolic pressure $(\mathrm{mmHg})$ & $90 \pm 11$ & $91 \pm 11$ & 0.6 \\
\hline \multicolumn{4}{|l|}{ Cardiovascular medication } \\
\hline ACE inhibitors or ARB, n (\%) & $63(79)$ & $59(74)$ & 0.34 \\
\hline Calcium channel blokers, n (\%) & $59(73)$ & $55(69)$ & 0.56 \\
\hline Beta blokers, n (\%) & $37(46)$ & $31(39)$ & 0.37 \\
\hline Cholesterol -lowering drugs, n (\%) & $54(67)$ & $56(70)$ & 0.73 \\
\hline
\end{tabular}

ACE, angiotensin converting enzyme; ARB, angiotensin receptor blocker; SV/PPi, ratio of stroke volume to pulse pressure; LDL-c, low-density lipoprotein cholesterol; HDL, high- density lipoprotein cholesterol

Table 2: Clinical and laboratory characteristics of subjects

\begin{tabular}{|c|c|c|c|}
\hline Variables & Decreased AC $(n=48)$ & Normal AC $(n=112)$ & $\mathbf{p}$ \\
\hline Age, years, $($ mean \pm SD) & $66 \pm 7$ & $54 \pm 6$ & $<0.001$ \\
\hline Male gender, $\mathrm{n}(\%)$ & $23(48)$ & $59(52)$ & 0.58 \\
\hline Smoking, n (\%) & $13(27)$ & $22(20)$ & 0.75 \\
\hline Diabetes, n (\%) & $10(21)$ & $17(15)$ & 0.39 \\
\hline Dyslipidemia, n (\%) & $42(87)$ & $90(81)$ & 0.26 \\
\hline fQRS, n (\%) & $31(64)$ & $50(44)$ & 0.021 \\
\hline \multicolumn{4}{|l|}{ Cardiovascular medication } \\
\hline ACE inhibitorsor ARB, n (\%) & $33(68)$ & $79(70)$ & 0.82 \\
\hline Calcium channel blokers, n (\%) & $28(58)$ & $85(76)$ & 0.025 \\
\hline Beta blokers, n (\%) & $20(42)$ & $48(43)$ & 0.97 \\
\hline Cholesterol -lowering drugs, n (\%) & $47(97)$ & $102(91)$ & 0.11 \\
\hline
\end{tabular}

$\mathrm{AC}$, arterial compliance with normal ( $\mathrm{SV} / \mathrm{PPi} \geq 0.6$ or decreased $(\mathrm{SV} / \mathrm{PPi}<0.6)$; $\mathrm{ACE}$, angiotensin converting enzyme; $\mathrm{ARB}$, angiotensin receptor blocker; $\mathrm{SV} / \mathrm{PPi}$, ratio of stroke volume to pulse pressure.

Table 3: Multivariable analysis for decreased arterial compliance $(\mathrm{SV} / \mathrm{PPi}<0.6)$

\begin{tabular}{lcccc}
\hline Variables* & SV/PPi $<\mathbf{0 . 6}$ & SV/PPi $>\mathbf{0 , 6}$ & OR (95\% CI) & p \\
\hline Age & $66 \pm 7$ & $54 \pm 6$ & $1.024(0697-0.830)$ & $<0.001$ \\
fQRS n $(\%)$ & $31(64)$ & $50(44)$ & $2.26(0.06-0.536)$ & 0.002 \\
\hline
\end{tabular}

*The covariates includes fQRS, age and calcium channel bloker use 


\section{DISCUSSION}

The current study showed that decreased arterial compliance values in asymptomatic hypertensive subjects with fQRS as well as a higher prevelance of fQRS in subjects with abnormal arterial compliance values, compared to those patients with normal arterial compliance. Each conduit arteries have arterial compliance and main decisive factor of compliance is increased blood pressure. One of the initial determinable finding of reverse structural and functional alterations inside of artery wall is impaired AC. Arterial compliance index of arterial elasticity is obtained by measuring exact change in area (or change in diameter $=\Delta \mathrm{D})$ for a given pressure $\operatorname{step}(\Delta \mathrm{P})$ at a constant vessel length. It is the responding of stiffness and is described as, $C=\Delta D / \Delta P$. Various invasive and non-invasive techniques have been described to assess $\mathrm{AC}$ and a different way to find arterial compliance is to calculate the $\mathrm{SV}$ to the $\mathrm{PP}$ ratio $(7,8)$. Other noninvasive technique of arterial compliance is Doppler derived SV/PPi and its clinical importance has been verified with variable patient population. In Type 2 DM patients, reduced AC is encountered although their blood pressure is within normal levels. This allows to clasify patients in terms of increased risk of adverse events. Lower AC, has been shown to be central to HFpEF (Heart failure with preserved ejection fraction) pathogenesis, leading to ventricular-arterial coupling left ventricular diastolic sub-clinical systolic dysfunction (9-11). Reduced compliance is related to excessive myocardial oxygen consumption and exacerbating ischemia $(12,13)$. The compliance of large elastic arteries decreases with advancing age. Particularly, several cardiovascular diseases, common in elderly, such as orthostatic hypotension, isolated systolic hypertension and left ventricular hypertrophy is associated with AC (14). In our study, we found that age was independent predictor of decreased AC.

LV hypertrophy and remodeling resulting from the interaction of hemodynamic and non-hemodynamic variables are fruquently seen in hypertensive patients. Arterial hypertension leads to increased afterload and consequetively hypertrophy of the left chamber of the heart and it causes increased left ventricular wall tension (15-17). Coronary microangiopathy occurs as a result of hypertrophy of the media wall thickness of the arteriolar vessel, resulting in decreased vascular autoregulation. All of these pathological circumstances lead to the development of myocardial fibrosis and are related to non-uniform activation of the left ventricle and guiding to terminal conduction delay or fQRS complex (18). It was shown in another study that the fQRS complex was associated with the extent of myocardial damage due to a decreased left ventricular ejection fraction (19). Younis et al. showed that the number and position of fQRS could predict the prognosis, occurrence of cardiogenic shock, and inhospital mortality (20). Additionaly, fQRS complexes on ECG is related with subendocardial fibrosis in nonischemic dilated cardiomyopathy (NDCM) patients (21). In a recently published study, Akyuz et al. investigated the association between fQRS and cardio ankle vascular index (CAVI) that is a noninvasive and novel parameter of arterial stiffness (22). They found that $\mathrm{fQRS}$ may provide a significant predictive value for arterial stiffness in asymptomatic subjects. Bonakdar et al. found that fQRS was valuable in predicting poor collateral coronary circulation in patients with chronic stable anjina (23). There are possible explanations for the relationship between AC and fQRS. As age increases, the heart undergoes fibrotic remodeling leading to progressive increase in ventricular stiffness and impaired diastolic dysfunction due to reduced arterial compliance. Based on these, we can say that presence of fQRS could be indicator of AC.

The major limitationof our study was the small sample size. Moreover, we included only hypertensive patients. Hence, our results are not appropriate to be applied to the general population. The present study 
was a cross-sectional design, and that's why decisive relationships could not be verified. Another important limitation of this study is that our patients did not have detailed echocardigraphic assesment such as left ventricular mass, hypertrophy and diastolic function. We certainly agree that these confounding factors may have significant impact on arterial stiffness. But our aim is simply to investigate the association between fQRS and arterial compliance. Impact of other confounding factors are beyond of our study.

ECG is simple, cheap, reproducible and readily available and interpreted by most of the physcians. Our study is the first study investigating the association between a simple diagnostic method and an important clinical endpoint.

As a result, the presence of fragmented QRS has considerable association with decreased arterial function in asymptomatic hypertensive patients. Investigation for the presence of fragmented QRS may be helpful in finding nonsymptomatic hypertensive patients with decreased arterial compliance who could benefit from more aggressive interventions and appropriate pharmacotherapy.

Conflict of Interest: None

Support and Acknowledgment: None

Researchers' Contribution Rate Statement: SŞ, LK, ÖFÇ, ARA conceived and planned. LK, SK, ARA analysed data, SŞ, MRS, AÖ wrote the manuscript. All authors discussed the results and contributed to the final manuscript.

Ethics Committe Aproval: Kanuni Education and Research Hospital Clinical Research Ethics Committee (Date: 17.02.2016; issue number: 2015/53).

\section{REFERENCES}

1. Lewington $\mathrm{S}$, Clarke $\mathrm{R}$, Qizilbash $\mathrm{N}$, Peto $\mathrm{R}$, Collins R. Prospective Studies Collaboration Age specific relevance of usual blood pressure to vascular mortality. Lancet. 2002;360(9349):190313.
2. Haluska BA, Jeffries L, Carlier S, Marwick TH. Measurement of arterial distensibility and compliance to assess prognosis. Atherosclerosis. 2010;209(2):474-80.

3. Avolio AP, Kuznetsova T, Heyndrickx GR, Kerkhof PLM, Li JK. Arterial flow, pulse pressure and pulse wave velocity in men and women at various ages. Adv Exp Med Biol. 2018;1065:15368.

4. Pannier BM, Avolio AP, Hoeks A, Mancia G, Takazawa K. Methods and devices for measuring arterial compliance in humans. Am J Hypertens. 2002;15(8):743-53.

5. Mancia G, De Backer G, Dominiczak A, Cifkova R, Fagard R, Germano G et al. 2007 guidelines for the management of arterial hypertension: the Task Force for the Management of Arterial Hypertension of the European Society of Hypertension (ESH) and of the European Society of Cardiology (ESC). J Hypertens. 2007;25(6):1105-87.

6. Mohty D, Pibarot P, Echahidi N, Poirier P, Dagenais GR, Dumesnil JG. Reduced systemic arterial compliance measured by routine Doppler echocardiography: a new and independent predictor of mortality in patients with type 2 diabetes mellitus. Atherosclerosis. 2012;225(2):353-8.

7. Oliver JJ, Webb DJ. Noninvasive assesment of arterial stiffness and risk of atherosclerotic events. Arterioscler Thromb Vasc Bio. 2003;23(4):554-66.

8. De Simone G, Roman MJ, Koren MJ, Mensah GA, Ganau A, Devereux RB. Stroke volume/pulse pressure ratio and cardiovascular risk in arterial hypertension. Hypertension. 1999;33(3):800-5.

9. Borlaug BA, Kass DA. Ventricular-vascular interaction in heart failure. Cardiol Clin. 2011;29(3):447-59.

10. Bell V, Sigurdsson S, Westenberg JJ, Gotal JD, Torjesen AA, Aspelund T et al. Relations between aortic stiffness and left ventricular structure and function in older participants in the Age, 
Gene/Environment

Susceptibility--Reykjavik

Study. Circ Cardiovasc Imaging. 2015;8(4):e003039.

11. Ye Z, Coutinho T, Pellikka PA, Villarraga HR, Borlaug BA, Kullo IJ. Associations of alterations in pulsatile arterial load with left ventricular longitudinal strain. Am J Hypertens. 2015;28(11):1325-31.

12. Otsuki T, Maeda S, Kesen Y, Yokohama N, Tanabe $\mathrm{T}$, Sugawara $\mathrm{J}$ et al. Age-related reduction of systemic arterial compliance induces excessive myocardial oxygen consumption during submaximal exercise. Hypertens Res. 2006;29(2):6573.

13. Haluska BA, Matthys K, Fathi R, Rozis E, Carlier SG, Marwick TH. Influence of arterial compliance on presence and extent of ischemia during stress Echocardiography. Heart. 2006;92(1):40-3.

14. Schillaci G, Battista F, Settimi L, Anastasio F, Pucci G. Cardio-ankle vascular index and subclinical heart disease. Hypertens Res. 2015;38(1):68-73.

15. Havranek EP, Emsermann CD, Froshaug DN, Masoudi FA, Krantz MJ, Hanratty $\mathrm{R}$ et al. Thresholds in the relationship between mortality and left ventricular hypertrophy defined by electrocardiography. J Electrocardiol. 2008;41(4):342-50.

16. Das MK, Khan B, Jacob S, Kumar A, Mahenthiran J. Significance of a fragmented QRS complex versus a $\mathrm{Q}$ wave in patients with coronary artery disease. Circulation. 2006;113(21):2495-501.

17. Armstrong AC, Gidding S, Gjesdal O, Wu C, Bluemke DA, Lima JA. LV mass assessed by echocardiography and CMR, cardiovascular outcomes, and medical practice. JACC Cardiovasc Imaging 2012;5(8):837-48.

18. Das MK, Suradi H, Maskoun W, Michael MA, Shen C, Peng J et al. Fragmented wide QRS on a 12-lead ECG: a sign of myocardial scar and poor prognosis. Circ Arrhythm Electrophysiol. 2008;1(4):258-68.

19. Ozcan KS, Güngör B, Tatlısu MA, Osmonov D, Ekmekçi A, Çalık AN et al. Presence of early repolarization on admission electrocardiography is associated with long-term mortality and MACE in patients with STEMI undergoing primary percutaneous intervention. $\mathrm{J}$ Cardiol. 2014;64(3):164-70.

20. Basaran Y, Tigen K, Karaahmet T, Isiklar I, Cevik C, Gurel E et al. Fragmented QRS complexes are associated with cardiac fibrosis and significant intraventricular systolic dyssynchrony in nonischemic dilated cardiomyopathy patients with a narrow QRS interval. Echocardiography. 2011;28(1):62-8.

21. Younis AS, El-HalagMI, ElBadry MA, Abbas NIM. Fragmented QRS complex frequency and location as predictor of cardiogenic shock and mortality following acute coronary syndrome. Egypt Heart J. 2020;72(1):43.

22. Akyuz AR, Sahin S, Cirakoğlu OF, Kul S, Turan T, Erkan H. Relation between fragmented QRS complex and cardioankle vascular index in asymptomatic subjects. Clin Exp Hypertens. 2021;43(4):368-72.

23. Bonakdar H, Moladoust H, Kheirkhah J, Abbaspour E, Assadian Rad M, Salari A et al. Significance of a fragmanted QRS complex in patients with chronic total occlusion of coronary artery without prior myocardial infarction. Anatol J Cardiol. 2016;16(2):106-12. 